\title{
Hope: Conceptual and normative issues
}

\section{Catherine Rioux}

Faculté de philosophie, Université Laval, Québec, Canada

\section{Correspondence}

Catherine Rioux, Faculté de philosophie, Université Laval, 2325 Allée des Bibliothèques, Québec, QC G1V 0A6, Canada.

Email: catherine.rioux@fp.ulaval.ca

\begin{abstract}
Hope is often seen as at once valuable and dangerous: it can fuel our motivation in the face of challenges, but can also distract us from reality and lead us to irrationality. How can we learn to "hope well," and what does "hoping well" involve? Contemporary philosophers disagree on such normative questions about hope and also on how to define hope as a mental state. This article explores recent philosophical debates surrounding the concept of hope and the norms governing hope. It also underlies hope's significance for the philosophy of emotion and the ethics of interpersonal relations.
\end{abstract}

\section{1 | INTRODUCTION}

Our hopes are multifarious, ranging from the mundane or the prosaic to the life-shaping or the profound: we hope that it won't rain tomorrow, hope for success in our personal endeavors, hope to be cured from life-threatening diseases, and hope that we will somehow overcome the climate crisis. At bottom, is there anything that sets apart our "deepest" hopes from more superficial ones? Or do all hopes, including even the kind we "invest" in other people, in fact share the same underlying nature? Since hope is often portrayed as both valuable and dangerous, questions about its nature take on special significance. We are indeed often told to "never give up hope"; that "there is always room for hope," while also being warned against the possibility of entraining "false hopes," somehow divorced from reality and potentially leading to disastrous outcomes. But without knowing what hope is, how can we aspire to hope well? And what does "hoping well" even mean?

Until quite recently, conceptual and normative questions about hope hadn't received much attention within the analytic tradition. This could be due, as Pettit (2004, p. 54) suggests, to the influence of a conception of hope emerging in the Modern period (notably in the works of Hobbes and Hume), according to which all hope consists in the combination of a desire for an outcome and the belief that outcome is possible but not certain. ${ }^{1}$ If all there is to hope is "desire in the context of epistemic uncertainty," ${ }^{2}$ then hope might not seem worthy of a standalone philosophical investigation. Attitudes toward hope's philosophical significance have now shifted, however, while hope also figures prominently in current public discourse. ${ }^{3}$ This article aims to take stock of these recent philosophical developments.

Section 2 turns to descriptive questions about the nature of hope, centering on the relationship between hope, desire, and the emotions, while Section 3 focuses on various evaluative measures used for assessing hope, in 
particular in terms of epistemic rationality, practical rationality and fittingness. It also explores the connections between hope, motivation to act and the rationality of action. Section 4 concludes by discussing outstanding issues for further research: the question of whether all hopes have "propositional content," and that of what "interpersonal hope" involves.

\section{2 | DESCRIPTIVE ISSUES: BELIEF, DESIRE, EMOTION}

Various theories of hope have recently been proposed to account for our self and other-directed ascriptions of hope. In continuity with early modern theories, proponents of the "standard view" analyze hope as the combination of a desire for an outcome and the belief that outcome is possible but not certain (see Day, 1969; Downie, 1963; Milona, 2019 for a contemporary defense). Often drawing on linguistic data (of the sort presented in Benton, 2020, Section 1 and Jackson (Forthcoming, Section 3.3), they note that conjoined ascriptions of hope that $p$ with desire that not- $p$ sound odd, as do conjoined ascriptions of hope that $p$ and knowledge or outright assertion of $p$ (or not- $p$ ). Because hope appears "knowledge-precluding," it seems constituted by a belief in the hoped-for outcome's possibility. And since we appear unable to hope for what we do not want (hope instead displaying some of the hallmarks of desire, through influencing action and patterns of attention), hope also seems constituted by a desire. We thus get the view that hope is simply a desire in the context of epistemic uncertainty.

While it is widely acknowledged that the standard account can make sense of many of our hopes (such as the hope "that you are well," or "that the train comes on time"), philosophers have recently doubted its capacity to account for "paradigmatic" instances of hope. They have relied on cases where two agents seem to entertain as strong a desire that $p$ and agree on $p$ 's probability of occurring, but nonetheless differ in their hopes. ${ }^{4}$ Martin's (2014, p. 14-16) Cancer Research, in particular, depicts two hypothetical patients, Alan and Bess, who both suffer from terminal cancer and have enrolled in an early-phase trial of an experimental drug. Their desires to be cured are equally strong, but they both know that there is a less than 1 percent chance that the drug will be successful. Whereas Bess' hope that "she will be the 1 percent" is "what keeps her going" (Martin, 2014, p. 15), Alan instead focuses on how slim his chances are, and does not have as strong a hope in a cure as Bess. Drawing on this case and similar ones, many have concluded that the standard account cannot capture intuitive differences in hope and must therefore be supplemented by some additional feature.

Philosophers have thus proposed what Blöser (2019, Section 1) calls "compound accounts," which equate hope with a more complex structure than a belief-desire pair. Meirav's (2009) "external factors" analysis of hope is one such view: Meirav argues that in addition to a desire for a state of affairs deemed uncertain, hope also involves seeing factors lying beyond one's "agential powers" as working in one's favor. 5 The "end-setting conception" of hope, on which hope is characterized by a form "agential investment" into bringing about the hoped-for outcome, can also be seen as a compound account. ${ }^{6}$ The majority of compound accounts, however, fall into two broad categories: "endorsement views" and "phenomenological views." While some accounts stress a form of active endorsement, on the subject's part, of her desire held in a context of epistemic uncertainty, others identify hope's "phenomenological aspects" (including its influence on the direction of attention and imagination) as essential to its structure. Accounts focused on endorsement typically face over-intellectualization worries: not all hopes seem to involve a form of "identification" with one's desires held under low odds. Accounts focused on hope's phenomenological dimensions, by contrast, often struggle to explain how those dimensions go beyond the phenomenological aspects of beliefs and desires seen as exhausting hope's nature on the standard view. They can thus be interpreted as inadvertently providing support for the standard view, as opposed to constituting a distinctive theoretical alternative.

Pettit's (2004) view of hope as "cognitive resolve" belongs to the first aforementioned category of compound accounts. Pettit suggests that substantial hope involves, in addition to a belief and a desire, a strategic decision to act "as-if" the hoped-for prospect were to obtain or were likely to obtain. Such a strategic decision to assume, in 
one's practical reasoning, that the desired outcome will or is likely to occur seems to constitute a form of endorsement of one's desire: one thereby lets one's attraction for the hoped-for outcome structure one's plans and actions. Moreover, Pettit's appeal to "cognitive resolve" seems to capture intuitive differences between Alan and Bess: whereas Bess seems to plan around the hoped-for outcome materializing, Alan does not.

But Pettit's proposal can be accused of "conflating a way of relating to a hope with a way of hoping" (Milona, 2019, p. 717). Not all of our hopes-both "trivial" and significant-seem to involve a strategic decision to act "as-if," as Pettit's account implies. Many instead appear "recalcitrant": they persist despite a belief or judgment that we ought not have them, and in the absence of a commitment let them guide our actions. ${ }^{7}$ Bovens (1999, p. 679), for instance, presents the case of a person attending a car race, who hopes to see a crash and feels ashamed of her hope, whereas Milona and Stockdale (2018, p. 209) focus on the hope of getting back with one's abusive ex-partner. None of these hopes seem to involve a kind of endorsement of one's desire for the hoped-for end, and even less a resolution to assume, in one's practical reasoning, that such desire will materialize.

A similar criticism can be raised against Martin's (2014) "incorporation analysis" of hope. On Martin's view, the hopeful see the hoped-for outcome's probability as "licensing" them to treat their desire for that outcome in a certain way: namely, as giving them "sufficient reasons" to engage in various "hopeful activities" (which include planning around the hoped-for outcome's realization, fantasizing about it and experiencing positive feelings of anticipation). ${ }^{8}$ According to Martin, what sets apart Bess from Alan is that she has incorporated her desire and probability assessment into a "justificatory rationale" for her hopeful feelings and activities, whereas he hasn't (2014, pp. 33-35; pp. 61-62). Here again, the phenomenon of recalcitrant hope seems to constitute a counterexample: some of our hopes exert a substantial influence on our planning, imagination and feelings, despite our failure to "incorporate" them and judge that we should engage in such activities. Moreover, it seems ad hoc to deny those hopes the labels of "significance" and "depth," despite what defenders of the incorporation analysis suggest."

By looking beyond desiderative endorsement to focus on hope's phenomenological aspects, we can avoid the objections just mentioned. Bovens (1999) defends such an alternative when he argues that hoping entails undergoing episodes of "mental imaging," in which one devotes "mental energy" to "what it would be like" if the hoped-for state of affairs were to materialize. In the same spirit, Calhoun (2018, Chapter 6) argues that hope requires adopting a "phenomenological idea of the successful future"-namely, a broadly unreflective sense of the future as unfolding as one desires. Both of these accounts identify important features of hopeful agents. But it is unclear whether they do so simply by zeroing in on manifestations of desire. For according to an influential conception (Scanlon, 1998), desire centrally involves dispositions to attend to the desired outcome's features and to imagine what it would be like for it to obtain. Given that Bess and Alan imagine and are attentive to very different things, we might doubt whether portraying them as having equally strong desires was accurate.

Milona (2019) argues that theories of hope need to rest on a better understanding of desire. He suggests that hopeful agents' belief in the hoped-for prospect grounds their desire for it (or figures in their desire's "cognitive base"), thereby influencing their desire's "character" (namely, the specific ways in which it structures motivation, attention, and feeling). On this view, Bess hopes for a cure, because her belief that being cured is possible exerts the kind of "direct influence" over her desire necessary for the grounding relation to obtain. Alan's desire, on the other hand, is "psychologically disconnected" from his belief that being cured is possible. It is in fact grounded in a different belief: the belief that "he will not be cured" (Milona, 2019, p. 721), hence his despair. Milona's arguments mark the return of the standard view as a serious option in the debate over hope's nature. However, portraying despairing agents as both believing that an outcome is possible and believing that it will not occur appears a high theoretical price to pay. For despair does not always seem to give rise to a tension in our beliefs concerning the desired prospect: it indeed seems possible to both despair that $p$ while remaining agnostic as to whether $p$ won't occur, contrary to what Milona suggests. In fact, compound accounts leave room for that very possibility: despairing agents who have not yet formed the belief that the outcome they desire won't occur might nonetheless differ from hopeful agents with respect to hope's "third element." 
I have so far focused on whether the belief that an outcome is possible and a desire for that outcome constitute sufficient conditions for hope. But some have recently come to doubt whether such conditions are even necessary. Segal and Textor (2015), in particular, question the very project of providing a reductive definition of hope: they argue that hope is a "primitive mental state," whose nature can be illuminated by attending to its "functional role" or place within a network of other mental states. In a similar vein, Döring (2014) claims that hope is an emotion: a "felt evaluation" representing its object as good and as possible; a sui generis representative state subject to its own rational standards or "correctness conditions." ${ }^{10}$ Despite what Döring's view suggests, classifying hope as an emotion does not necessarily amount to a rejection of the "compound approach," or even to a rejection of the standard view. For hope might have cognitive, conative, and emotional components (see McGeer, 2004, p. 101; Milona \& Stockdale, 2018, pp. 207-212; Urban Walker, 2006, p. 48), or its emotional dimension might even be identifiable with that of desire (see Milona, 2019, Section 5.3). In fact, as we will see shortly, whether hope is an emotion does not only have implications for debates over its nature: it can also direct the inquiry into its proper evaluative standards.

\section{3 | NORMATIVE ISSUES: RATIONALITY, FITTINGNESS, ACTION}

We routinely evaluate each other's hopes: we praise people who hope for unlikely outcomes as "courageous" or "resilient," but also criticize them as "careless" or "irrational." From a philosophical perspective, our evaluative practices surrounding hope can be captured by distinct sets of norms. This section seeks to examine them, in addition to exploring the connection between hope and rational action.

We can first evaluate hope's epistemic rationality. Many have noted that a hope-constituting belief in the hoped-for outcome's possibility is irrational if one possesses good evidence that such an outcome is in fact not possible, or good evidence that it is instead certain. ${ }^{11}$ One's probability assessment also seems beholden to evidential norms: an agent who possesses very good evidence that the outcome he hopes for is possible, but for will not materialize, should not remain quite confident that it will. He should instead proportion his degree of confidence in the hoped-for outcome's occurrence to the evidence (Calhoun, 2018, p. 48, Martin, 2014, p. 87). Low probability estimates are consistent with strong hopes (see Martin, 2014, p. 5; p. 141; McCormick, 2017, p. 132), but they have to be evidentially grounded.

In and of themselves, evidential norms do not place very stringent constraints on hope. But hope can also be assessed for practical or "strategic" rationality (Bovens, 1999, Section 3; Calhoun, 2018, pp. 86-88; Martin, 2014, pp. 48-52; Pettit, 2004, p. 160). This is because substantial hope can have a significant impact on our motivation to act: since there are situations where "getting ourselves to hope" would constitute a fruitful means of achieving our ends, hope seems up for evaluation in instrumental terms. Moreover, because hope-constituting beliefs and desires are already subject to their own evaluative standards (in terms of epistemic rationality and "fittingness," respectively and as we will see), hope's putative additional dimensions have often been the focus of practical rationality evaluations. Thus Martin (2014, p. 63) argues that the "gestalt shift" which she takes to characterize hope (and which involves "emphasizing possibility over probability"), is governed by practical norms only: whereas Bess' seeing the hoped-for outcome as unlikely, but possible, coheres well with her plans and her "rational scheme of ends" ("perhaps she needs such a strong investment to keep her scheme from falling apart"), Alan's seeing the hoped-for outcome as possible, but unlikely, best coheres with his ("perhaps he needs to dedicate greater energy to preparing for his death to prevent his scheme from falling apart"). Blöser and Stahl (2017) add that adopting a hopeful, "as-if attitude" toward the hoped-for outcome's probability can count as practically rational even when it does not promote a definite set of the agent's ends. They argue that seeing certain low probabilities as giving oneself reasons to engage in various hopeful activities can instead be partly constitutive of one's own personal identity, and therefore intrinsically valuable. 
The epistemic and practical dimensions of assessment can come apart: a given hope can be practically rational because it coheres well with one's overall set of ends, but epistemically irrational because constituted by a flawed probability assessment, and vice versa. ${ }^{12}$ But can a hope that satisfies both epistemic and practical constraints nonetheless be rightfully criticized? To be sure, the issue is not whether some hopes are morally problematic (a question touched on in the last section). It is instead whether some evidentially supported, instrumentally rational hopes can nonetheless fail as hopes, or in light of a certain standard determining what hope is, as a mental representation.

Some philosophers (including Döring, 2014; Milona \& Stockdale, 2018; Stockdale, 2020a and plausibly others working in the philosophy of emotion) ${ }^{13}$ believe so: they hold that hope can be assessed for "fittingness," an evaluative dimension irreducible to epistemic or practical rationality. Fitting emotions correctly represent their objects as having certain evaluative features: ${ }^{14}$ fear, for instance, counts as fitting if it accurately represents the evaluative property of "being fearsome." Hope, Milona and Stockdale (2018, p. 211) suggest, is fitting when, in addition to being directed at a valuable prospect, it also accurately represents the desired outcome's probability as "encouraging." Milona and Stockdale argue (drawing on the work of D'Arms and Jacobson, 2000; 2003) that fittingness is a function of both the "shape" and "size" of one's hope. Bess' hope for a cure is fitting in terms of shape, because it is directed at a truly valuable prospect that is possible. But it is not fitting in terms of size, and actually "overblown": considering Bess' dismally low probability of being cured, the odds are not "encouraging," and a strong hope therefore unfitting.

If Milona and Stockdale are right, then we are entitled to criticize agents who pin strong hopes on highly unlikely outcomes, even when those hopes are practically rational and grounded in an accurate probability estimate. However, we might wonder whether there are in fact cases where hope's being fitting and its being practically rational come apart. Whether a strong hope for a highly unlikely outcome is acceptable might instead both depend on whether its constituting desire is fitting (which, in turn, plausibly depends on whether it is directed at a truly valuable outcome and experienced in proportion to that outcome's goodness), ${ }^{15}$ and also a function of whether "getting oneself to hope" is practically rational. Consistent with that line of thought, Martin (2014, pp. 50-51) traces back our negative verdicts concerning hopes for highly unlikely outcomes to their practical irrationality: considering the low probability for such hopes to materialize, agents would often be better off, from the practical point of view of promoting their overall schemes of ends, if they relinquished them. It is thus unclear whether evaluations of hope's fittingness go beyond evaluations of its constitutive desire's fittingness and hope's practical rationality.

We have so far focused on norms governing hope as a mental state. But hope's influence on action is also the object of our evaluative judgments. For many endow hope with a unique "motivational power" or capacity to help us face even the direst of circumstances: hope is seen as the "light" or "beacon" that sustains us through loss of creative inspiration, disease, wartime, natural disaster, etc. Aquinas (1912 [1265-1274], 1a 2ae Q40 Art. 1) describes hope as an "irascible passion"; a special motivational force directed at obstacles to our desires, and better suited to deal with them than desire itself. Philosophical and nonphilosophical depictions of hope thus raise two important questions: first, is hope's "motivational power" wholly reducible to that of desire? And can hope contribute to the rationality (or irrationality) of action in ways distinct from those of desire?

On one set of views, hope owes its apparent distinctive motivational efficacy to its desire component, and rationalizes action in the same way as desire. Jackson (Forthcoming), for instance, argues that substantial hope typically involves a very strong desire. Only by acknowledging such a strong conative component, she insists, can we both locate the source of hope's motivating power and distinguish it from faith. ${ }^{16}$ Along similar lines, Martin (2014, Chapter 3) argues that hope, in itself, does not have motivational effects going beyond those of desire, but that one typical way of "expressing hope" (namely, through "fantasizing") does. By actively imagining the hoped-for outcome materializing, we can, according to Martin, discover some of its previously unacknowledged positive features and thus reinforce our desire in it. ${ }^{17}$ 
These proposals, although insightful, do not seem to exhaust hope's contribution to motivation and rational action. For as Calhoun (2018, pp. 84-86) emphasizes, motivation, in beings like ourselves, does not seem fully determined by cognitive states poised to enter in practical deliberation, such as beliefs and desires. It also seems shaped by our "general sense of what the future will bring," or what Calhoun calls our "phenomenological idea of the future." Calhoun explains that those who despair for an outcome "previsage" the future as including failure, which leads them to see their current efforts to bring about the hoped-for outcome as wasted, in turn undermining their motivation to pursue it. The hopeful, by contrast, entertain an idea of the future containing success. Since such an idea enables them to act in line with their desires, and thus do what they already judge they ought to, hope can remove phenomenological, volitional barriers to rational action. This means that its motivational influence is not limited to its capacity to strengthen desire.

\section{AVENUES FOR FUTURE RESEARCH: BEYOND PROPOSITIONAL HOPE}

This article has so far centered on "propositional hope": whether one hopes for clement weather at one's wedding, or to overcome disease, one's hopes seem directed at propositions representing the world's being a certain way. But do all forms of hope in fact have this propositional structure? Or are some varieties of hope nonpropositional in nature, and thus left out by current conceptual and evaluative frameworks? Here, two important varieties of hope, namely "basal hope" (Calhoun, 2018; Ratcliffe, 2010, 2013) and "interpersonal hope" (Martin, 2014, Chapter 5, 2020; Stockdale, 2020b, Chapter 6), stand out, each being the focus of sustained, ongoing debate.

We can uncover the phenomenon of "basal hope" by turning to that of "loss of hope." Loss of hope appears conceptually distinct from disappointment: whereas our hopes that $p$ are "dashed" whenever we learn that not- $p$, mere loss of hope that $p$ seems compatible with current ignorance as to whether $p$. Obviously, some statements of the form "I have lost all hope" and "All I can feel is utter despair" communicate the extinction of particular propositional hopes. But Ratcliffe (2013, p. 600) argues that not all of them do: some instead point to the loss of a "preintentional orientation," "existential feeling," or "experiential backdrop," determining "which kinds of intentional states count as eligible possibilities for a person." ${ }^{18}$ As an affectively laden mode of anticipating the future as "sufficiently hospitable to our agential efforts" (Calhoun, 2018, p. 74), basal hope does not only imbue our various future-oriented propositional hopes and desires with meaning: it also has motivational effects. Thus, depressed agents who have lost basal hope (for instance through the loss of a significant other, or because of enduring illness) can still retain various propositional hopes for particular outcomes. Only, insofar as they now view the content of some of those hopes as "meaningless," they remain unmoved by them, even in the absence of countervailing motivations to act (see Ratcliffe 2013, pp. 605-608). Losing particular propositional hopes while maintaining basal hope is also possible, as exemplified by Chief Plenty Coups' "radical hope" (portrayed by Lear, 2006; see Ratcliffe, 2013, pp. 603-604). Despite facing the utter destruction of the Crow way of life (and thus the shattering of many of his propositional hopes), Plenty Coups (or Alaxchiiaahush, his Crow name) succeeds at retaining a sense of the future as leaving room for "the possibility of new Crow possibilities" (Lear, 2006, pp. 94-98). He thereby preserves his motivation to lead the Crow people into a "new way of life"whatever that entails. ${ }^{19}$

Perhaps surprisingly, considering its plausible relation to human motivation, basal hope has been little theorized by philosophers and psychologists. ${ }^{20}$ Some important questions about its nature thus remain. These include whether it could in fact adequately be seen as a form of propositional hope ranging over a very broad content (Milona \& Stockdale, 2018, pp. 218-219), and whether it could be construed as a capacity or disposition to hope, as opposed to a state with a distinct phenomenological feel (Ratcliffe, 2013, p. 600).

Another variety of hope also appears left out by current analyses: "interpersonal hope," or the kind of hope we "invest" or "place" in other people. ${ }^{21}$ Martin (2020) argues that in addition to being an attitude toward propositions, this sort of hope constitutes a "second-personal" way of relating to others as agents or "reasoners." 22 
We can distinguish interpersonal hope from "mere" propositional hope by turning to its typical manifestations: interpersonal hope that fails to materialize often gives rise to a singular feeling of "being let down by someone"feeling which seems nonequivalent to mere disappointment. To illustrate: I might feel disappointed when it starts raining on my wedding day, but feeling "let down" seems out of place. Likewise when my friend fails to develop a new interest in, say, bread-baking: upon realizing that she will never be involved in such a pursuit, I might rightfully be disappointed, even though feeling that she has let me down would be inappropriate. By contrast, we can imagine a father who "hopes that his daughter will have a more fulfilling and comfortable life than he has" (Martin, 2020). Such a hope motivates certain actions: as the father tries to provide opportunities for his child and thus promote the hoped-for outcome, he invests significant resources, both material and "agential." When the child nears adulthood and fails to take advantage of these opportunities, the father can, it seems, rightfully feel let down in a distinctive, "second-personal" sense. That is, he might feel that his daughter has let him down, her failure to conform to his expectations marking a lack of appreciation for his investment into her future.

A satisfying account of interpersonal hope should uncover what grounds such a second-personal feeling of "being let down" and identify what makes it apt. Martin (2020) argues that interpersonal hope centrally involves a desire for "extending one's agency through another person" so as to produce a certain outcome, as well as a belief that outcome's occurring through such an extension is possible. Her account raises important questions about the ethics of interpersonal hope. In particular, is it ever morally appropriate for the "investor" to hope to contribute to an outcome that the "investee" does not also desire? Or is a mutually shared desire for an outcome a precondition for morally appropriate interpersonal hope? Importantly, one might see the hoper's investment into the investee as a form of "scaffolding"-namely, as a kind of "proleptic mechanism" leading the investee to pursue an outcome that she does not yet fully value, but later will. ${ }^{23}$ How can our evaluations of interpersonal hope's moral appropriateness take such a proleptic dimension into account? Such questions can only be answered by paying close attention to the ethics of "giving" and "receiving" hope. ${ }^{24}$

My aim was to show that hope is a fruitful and important topic of philosophical inquiry. Hope influences our motivation, the rationality of our actions, our other emotions and the unfolding of our mental lives, in addition to being a distinctive way of relating to others. As hope becomes an active topic of philosophical research, we stand to gain new insights into "hoping well," and thus learn how to cultivate more realistic, more sustaining and more ethical hopes.

\section{ACKNOWLEDGMENT}

Thanks to Elizabeth Jackson, Michael Milona, Katie Stockdale and Christine Tappolet for comments on an earlier draft. Thanks also to Simon-Pierre Chevarie-Cossette, Samuel Dishaw, Atoosa Kasirzadeh and Manish Oza for stimulating discussions. Finally, many thanks to Ronald de Sousa, Sarah Stroud and to my dissertation committee (David Barnett, Sergio Tenenbaum, Philip Clark and Jennifer Nagel) for comments and feedback on previous versions of this material.

\section{ORCID}

Catherine Rioux (D) https://orcid.org/0000-0003-4501-8493

\section{ENDNOTES}

${ }^{1}$ See Hobbes (1994 [1651], par. 14-19), Hume (1975 [1740], 2.3.9). For a recent overview of theories of hope in the history of philosophy, see Blöser \& Stahl's collection of essays (2020, Part I).

2 To borrow Martin's (2014, p. 11) expression.

${ }^{3}$ For vivid examples of "hope discourse" in politics, see Blöser, Huber, and Moellendorf (2020). See also Stahl (2020).

4 See Meirav's (2009, p. 222) Shawshank Redemption case, Moellendorf's (2006, p. 419) political activists case and Segal and Textor (2015, p. 209) mountaineers case.

${ }^{5}$ For a critical discussion of Meirav's (2009) view, see Martin (2014, pp. 19-20).

6 I borrow this expression from Martin (2014, p. 64), who sees the end-setting conception as encompassing both McGeer's (2004) and Urban Walker's (2006) views. 
7 The present notion of "recalcitrance" is familiar from debates in the philosophy of emotion, where recalcitrant emotions are defined as those persisting despite a conflicting judgment. For discussion, see Roberts (1988), Greenspan (1988), D'Arms \& Jacobson (2003). See also Milona \& Stockdale (2018, p. 208).

${ }^{8}$ For a precursor to Martin's account, see Moellendorf's argument (2006, esp. pp. 420-422) that taking one's beliefs and desires as reasons for action constitutes a necessary condition for hoping.

9 See in particular Martin (2014, p. 62), where she claims that hope "in the fullest sense" or "full-fledged hope" requires incorporation.

10 See Döring (2003) for an account of the emotions as "affective perceptions" with a "representational, intentional content." See also Blöser (2019, pp. 209-211) for a rejection of desire and belief as necessary conditions.

11 The relevant sense of possibility appears at least "metaphysical," and possibly "nomological." See Chignell (2013), Day (1969, p. 89).

12 McCormick (2017) argues that both set of norms should factor equally into our assessment of hope's "overall" or "allthings-considered" rationality, such that a high score on one dimension can "compensate" for a low score on the other.

13 See for instance Tappolet (2016, p. 5; pp. 25-26), who classifies hope among the "positive emotions." Tappolet develops a theory of the emotions as "perceptual experiences of value," up for evaluation in terms of accuracy (see Tappolet, 2016, pp. 87-89). On the view that hope is an emotion and therefore subject to distinct evaluative standards, see also Helm (2009, pp. 250-252) and Ben-Ze'ev (2001, Chapter 16).

14 For more on the notion of fittingness, see Howard (2018). Philosophers of hope who draw on the philosophy of emotion typically accept what Howard (2018, p.6) calls the "Alethic View" of fittingness (due to its emphasis on representational accuracy). Such an account of fittingness is especially popular among those who take emotions to involve normative assessments or perceptions. On the perceptual model of the emotions, see Solomon (1976), de Sousa (1987, 2002, 2011), Greenspan (1988), Roberts (2003), Döring (2003, 2007), Prinz (2004, 2007) and Tappolet (2000, 2016).

15 Here I follow defenders of fittingness assessments of hope in assuming what Howard (2018, p. 6) calls the "Alethic View." Combined with an influential view of desire on which they are perceptual-like experiences of the good (or, alternatively, of reasons) (see Oddie, 2005; Scanlon, 1998; Stampe, 1987; Tenenbaum, 2007), we get the claim that desire as an emotion is fitting when it accurately represents its object as good (or as giving one reasons to pursue it).

16 I cannot address the relation between hope and faith here. Jackson (Forthcoming) argues that while hope typically has a stronger conative component than faith, faith typically has a stronger epistemic component than hope. The balance between faith's two components is supposed to make it especially well-suited to rationalize perseverance in the face of challenges or "trials." For more on the relationship between hope and faith (and especially secular faith), see Martin (2014, Chapter 4), where Martin draws on the work of Marcel (1962). It would be interesting to contrast Pettit's (2004) view of hope as "cognitive resolve" with Buchak's (2012, 2017) view of faith as a commitment to take on risks on the basis of a proposition's being true without searching for further evidence.

17 Relatedly, Bobier (2017) argues that hope (which he defines following the "standard analysis") is necessary for practical deliberation (see Mueller, 2019 for a reply centering on the notion of substantial hope). Rioux (Forthcoming) argues that hope in one's future success in difficult projects can constitute a distinctive source of "grit" (defined as the capacity for perseverance).

18 Ratcliffe draws on his previous work on "preintentional emotions" as "bodily feelings" having as their objects background orientations presupposed by intentional states. See Ratcliffe (2008, 2010). On basal emotions, see also Dillon (1997) and Jones (2004).

19 Martin (2014, pp. 98-101) depicts Plenty Coup's hope as a kind of "unimaginable hope" that "outstrips his available concepts," while Ratcliffe (2013, pp. 603-604) emphasizes its role in maintaining various meaningful possibilities for particular propositional hopes open, through constituting a "general sense of the future" as "bringing something good."

20 As Ratcliffe (2013, pp. 599-600) notes, the "Beck Hopelessness Scale" (Beck, Weissman, Lester, \& Trexler, 1974) is insensitive to the distinction between hopefulness as the loss of particular propositional hopes and hopefulness as the loss of basal hope. The same could be said of Snyder's Adult Dispositional Hope Scale (Snyder et al., 1996). For recent discussions of hope as a psychological construct, see Rose and Sieben (2017), Gallagher, D'Souza, and Richardson (2020).

21 Discussions of such a form of hope seem prominent within the Christian tradition. Aquinas, for instance, appears to explain the Christian virtue of hope in terms of hoping in God. See Aquinas (1912 [1265-1274], 2.2.17), Lamb (2016).

22 It can thus ground "reactive attitudes" in Strawson's (1974) sense-in particular, the attitude of pride in the investee and that of "second-personal disappointment." Moreover, as Martin (2020) explains, we usually invest hope in people whom we know "interpersonally." On interpersonal knowledge and knowledge of persons, see Stump (2010, Chapters 3-5), Talbert (2015), Benton (2017).

23 On proleptic reasons and close interpersonal relations, see Callard (2018, Chapter 2). Fricker (2016) defines a proleptic mechanism as a way of treating someone as if they already recognized a reason that they do not yet fully appreciate, and which has the effect of leading them to then recognize that reason. 
24 As Martin (2014, pp. 2-4) notes, most discussions of the ethics of hope have so far occurred in bioethics (see for instance Martin, 2008). Other discussions also occur at the intersection of political philosophy (see for instance Stockdale (2020b) for an account of how political oppression makes the oppressed especially vulnerable to exploitation through the maintenance of unfitting hope). See also Snow (2020) for a virtue-theoretic approach to the ethics of hope in continuity with McGeer's (2004) work, as well as Kadlac (2015), Bobier (2018) and Milona (Forthcoming) on whether hope is a moral virtue.

\section{REFERENCES}

Aquinas, T. (1912 [1265-1274]). Summa theologica. London, UK: Burns, Oates \& Washbourne.

Beck, A. T., Weissman, A., Lester, D., \& Trexler, L. (1974). The measurement of pessimism: The hopelessness scale. Journal of Consulting and Clinical Psychology, 42, 861-865.

Ben-Ze'ev, A. (2001). The subtlety of emotions. Cambridge, MA: MIT Press.

Benton, M. (2017). Epistemology personalized. The Philosophical Quarterly, 67(269), 813-834.

Benton, M. (2020). Epistemological aspects of hope. In C. Blöser \& T. Stahl (Eds.), The moral psychology of hope. London, UK: Rowman \& Littlefield.

Blöser, C. (2019). Hope as an irreducible concept. Ratio, 32, 205-214.

Blöser, C., Huber, J., \& Moellendorf, D. (2020). Hope in political philosophy. Philosophy Compass, 15, 1-9.

Blöser, C., \& Stahl, T. (2017). Fundamental hope and practical identity. Philosophical Papers, 46(3), 345-371.

Blöser, C., \& Stahl, T. (2020). The moral psychology of hope. London, UK: Rowman \& Littlefield.

Bobier, C. (2017). Hope and practical deliberation. Analysis, 77(3), 495-497.

Bobier, C. (2018). Why hope is not a moral virtue: Aquinas's insight. Ratio, 31(2), 214-232.

Bovens, L. (1999). The value of hope. Philosophy and Phenomenological Research, 59(3), 667-681.

Buchak, L. (2012). Can it be rational to have faith? In J. Chandler \& V. Harrison (Eds.), Probability in the philosophy of religion (pp. 225-247). Oxford, UK: Oxford University Press.

Buchak, L. (2017). Faith and steadfastness in the face of counterevidence. International Journal for Philosophy of Religion, 81, $113-133$.

Calhoun, C. (2018). Doing valuable time: The present, the future, and meaningful living. New York, NY: Oxford University Press.

Callard, A. (2018). Aspiration: The agency of becoming. New York, NY: Oxford University Press.

Chignell, A. (2013). Rational hope, moral order, and the revolution of the will. In E. Watkins (Ed.), Divine order, human order, and the order of nature (pp. 197-218). New York, NY: Oxford University Press.

Day, J. P. (1969). Hope. American Philosophical Quarterly, 6(2), 89-102.

de Sousa, R. (1987). The rationality of emotion. Cambridge, MA: MIT Press.

de Sousa, R. (2002). Emotional truth. Proceedings of the Aristotelian Society, 76, 247-263.

de Sousa, R. (2011). Emotional truth. New York, NY: Oxford University Press.

Dillon, R. (1997). Self-Respect: Moral, emotional, political. Ethics, 107(20), 226-249.

Döring, S. (2003). Explaining action by emotion. The Philosophical Quarterly, 53(211), 214-230.

Döring, S. (2007). Seeing what to do: Affective perception and rational motivation. Dialectica, 61(3), 363-394.

Döring, S. (2014). What is an emotion? Musil's adverbial theory. The Monist, 97(1), 47-65.

Downie, R. S. (1963). Hope. Philosophy and Phenomenological Research, 24(2), 248-251.

D'Arms, J., \& Jacobson, D. (2000). The moralistic fallacy: On the appropriateness of emotions. Philosophy and Phenomenological Research, 61(1), 65-90.

D'Arms, J., \& Jacobson D. (2003). The significance of recalcitrant emotion (or, anti-quasijudgmentalism). In A. Hatzimoysis (Ed.), Philosophy and the emotions (pp. 127-146). Cambridge, UK: Cambridge University Press.

Fricker, M. (2016). What's the point of blame? A paradigm-based explanation. Noûs, 50(1), 165-183.

Gallagher, M. W., D'Souza, J. M., \& Richardson, A. L. (2020). Hope in contemporary psychology. In C. Blöser \& T. Stahl (Eds.), The moral psychology of hope. London, UK: Rowman \& Littlefield.

Greenspan, P. (1988). Emotions and reasons: An inquiry into emotional justification. New York, NY: Routledge.

Helm, B. (2009). Emotions as evaluative feelings. Emotion Review, 1, 248-255.

Hobbes, T. (1994 [1651]). In E. Curley (Ed.), Leviathan. Indianapolis, IN. Hackett.

Howard, C. (2018). Fittingness. Philosophy Compass, 13(11), 1-14.

Hume, D. (1975 [1740]). In L. A. Selby-Bigge \& P. H. Nidditch (Eds.), A treatise of human nature. Oxford, UK: Clarendon Press. Jackson, E. (Forthcoming). Belief, faith, and hope: On the rationality of long-term commitment. Mind.

Jones, K. (2004). Trust and terror. In P. DesAutels \& M. Urban Walker (Eds.), Moral psychology: Feminist ethics and social theory (pp. 3-18). Lanham, MD: Rowman \& Littlefield.

Kadlac, A. (2015). The virtue of hope. Ethical Theory \& Moral Practice, 18(2), 337-354.

Lamb, M. (2016). Aquinas and the virtues of hope: Theological and democratic. Journal of Religious Ethics, 44, 300-332.

Lear, J. (2006). Radical hope: Ethics in the face of cultural devastation. Cambridge, MA: Harvard University Press. 
Marcel, G. (1962). Sketch of a phenomenology and metaphysic of hope. In Homo viator: Introduction to a metaphysic of hope (pp. 23-61). Translated by E. Crawford. New York, NY: Harper Torchbooks.

Martin, A. (2008). Hope and exploitation. Hastings Center Report, 38(5), 49-55.

Martin, A. (2014). How we hope: A moral psychology. Princeton, NJ: Princeton University Press.

Martin, A. (2020). Interpersonal hope. In C. Blöser \& T. Stahl (Eds.), The moral psychology of hope. London, UK: Rowman \& Littlefield.

McCormick, M. (2017). Rational hope. Philosophical Explorations, 20(1), 127-141.

McGeer, V. (2004). The art of good hope. The Annals of the American Academy of Political and Social Science, 59(1), 100-127. Meirav, A. (2009). The nature of hope. Ratio, 22(2), 216-233.

Milona, M. (Forthcoming). Discovering the virtue of hope. European Journal of Philosophy.

Milona, M. (2019). Finding hope. Canadian Journal of Philosophy, 49(5), 710-729.

Milona, M., \& Stockdale, K. (2018). A perceptual theory of hope. Ergo, 5(8), 203-222.

Moellendorf, D. (2006). Hope as a political virtue. Philosophical Papers, 35(3), 413-433.

Mueller, A. (2019). Hopeless practical deliberation - reply to Bobier. Analysis, 79(4), 629-631.

Oddie, G. (2005). Value, reality, and desire. New York, NY: Oxford University Press.

Pettit, P. (2004). Hope and its place in mind. The Annals of the American Academy of Political and Social Science, 592, $152-165$.

Prinz, J. (2004). Gut reactions: A perceptual theory of emotion. New York, NY: Oxford University Press.

Prinz, J. (2007). The emotional construction of morals. Oxford, UK: Oxford University Press.

Ratcliffe, M. (2008). Feelings of being: Phenomenology, psychiatry and the sense of reality. Oxford, UK: Oxford University Press.

Ratcliffe, M. (2010). Depression, guilt and emotional depth. Inquiry, 53, 602-626.

Ratcliffe, M. (2013). What is it to lose hope? Phenomenology and the Cognitive Sciences, 12(4), 597-614.

Rioux, C. (Forthcoming). Hope as a source of grit. Ergo.

Roberts, R. (1988). What an emotion is: A sketch. Philosophical Review, 97(2), 183-209.

Roberts, R. (2003). Emotions: An essay in aid of moral psychology. Cambridge, UK: Cambridge University Press.

Rose, S., \& Sieben, N. (2017). Hope measurement. In M. W. Gallagher \& S. J. Lopez (Eds.), The Oxford handbook of hope. New York, NY: Oxford University Press.

Scanlon, T. M. (1998). What we owe each other. Cambridge, MA: Belknap Press.

Segal, G., \& Textor, M. (2015). Hope as a primitive mental state. Ratio, 28(2), 207-222.

Snow, N. (2020). Is hope a moral virtue? In C. Blöser \& T. Stahl (Eds.), The moral psychology of hope. London, UK: Rowman \& Littlefield.

Snyder, C. R., Sympson, S. C., Ybasco, F. C., Borders, T. F., Babyak, M. A., \& Higgins, R. L. (1996). Development and validation of the state hope scale. Journal of Personality and Social Psychology, 70(2), 321-335.

Solomon, R. (1976). The passions. Garden City, NY: Anchor Press/Doubleday.

Stahl, T. (2020). Political hope and cooperative community. In C. Blöser \& T. Stahl (Eds.), The moral psychology of hope. London, UK: Rowman \& Littlefield.

Stampe, D. (1987). The authority of desire. Philosophical Review, 96(3), 335-381.

Stockdale, K. (2020a). Emotional hope. In C. Blöser \& T. Stahl (Eds.), The moral psychology of hope. London, UK: Rowman \& Littlefield.

Stockdale, K. (2020b). Hope under oppression (Unpublished Manuscript).

Strawson, P. F. (1974). Freedom and resentment and other essays. London, UK: Methuen.

Stump, E. (2010). Wandering in darkness: Narrative and the problem of suffering. New York, NY: Oxford University Press.

Talbert, B. (2015). Knowing other people: A second-person framework. Ratio, 28(2), 190-206.

Tappolet, C. (2000). Émotions et valeurs. Paris, France: Presses Universitaires de France.

Tappolet, C. (2016). Emotions, value, and agency. Oxford, UK: Oxford University Press.

Tenenbaum, S. (2007). Appearances of the good: An essay on the nature of practical reason. New York, NY: Cambridge University Press.

Urban Walker, M. (2006). Moral repair: Reconstructing moral relations after wrongdoing. Cambridge, UK: Cambridge University Press. 


\section{AUTHOR BIOGRAPHY}

Catherine Rioux is an Assistant Professor at Université Laval (Quebec City). Her research is at the intersection of moral psychology, philosophy of action and traditional epistemology. She is particularly interested in the relation between hope, motivation to act and practical rationality, as well as in ethical constraints over hope. Her research interests also include the philosophy of emotion, with a focus on emotion and diachronic agency. She completed her Ph.D. in Philosophy at the University of Toronto.

How to cite this article: Rioux C. Hope: Conceptual and normative issues. Philosophy Compass. 2021;1-11. https://doi.org/10.1111/phc3.12724 